\title{
HISTORY OF NATURE SASKATCHEWAN'S VAN BRIENEN LAND NATURE SANCTUARY
}

\section{Brian Irving}

Box 727

Kelvington, SK SOA 1W0

bcirving@sasktel.net

William and Henrietta Harrison came from Formby (Liverpool) England and were married at Baldur, Manitoba on April 30, 1906. William had been a farm labourer there for the past year. Both he and Henrietta had grown up in urban areas and had little experience with farm life, never mind living in the wilderness, but were well educated. William had started training as a Methodist minister and Hettie was a Sunday school teacher.

In June of 1906, William and his brother went to the Wadena, Saskatchewan area to look for a homestead. The railway line ended at Sheho, so they caught a ride with another settler — who had a team and wagon - the rest of the way. On June 14, William walked to Paswegin to file his homestead claim. It seems the government kept moving the Land Titles ahead of the end of the rail so it would be accessible to the land seekers. William chose a quarter section on to which a shallow lake extended. This lake (identified as Lake No 1 on a Township Plan dated $12^{\text {th }}$ of August 1902) later became known locally as Meadow Bank Lake. A Meadowbank Post Office operated for a number of years in a farm house at the east end of the lake. The Harrison home was a mile and a half to the west. William saw the lake as an asset as it would supply water for livestock and lush grass grew nearby.

The two men went back to Manitoba for the summer and returned to their homesteads in the fall. William proceeded to build a small two-room cabin in which to spend the winter with his bride. As a result of frequent prairie fires during previous decades, the land did not have many tall, straight trees for building. On the advice of his neighbours, William built the cabin with small, rail-sized poles - to stand vertically for walls - and a pole and sod roof. William's brother, Howard, built his home a mile away using short but sturdy logs. He was innovative and fashioned a six-sided building to create more floor space. The stove pipe went up the centre.

The Harrisons could not afford to buy furniture, so Will built his own bedsteads, chairs, tables, etc. out of poplar trees. He even built some to sell. Thus, the young couple began married life in their cabin in the winter of 1906-07. History has shown this to be one of the most severe winters on the prairies.

The summer of 1907 was spent making improvements and working for more established farms. On January 12, 1908, their first child, Eva, was born in the two-room cabin by the lake. A nearby neighbour had midwifery skills and was prepared for the birth. However, some problems occurred and she told William to

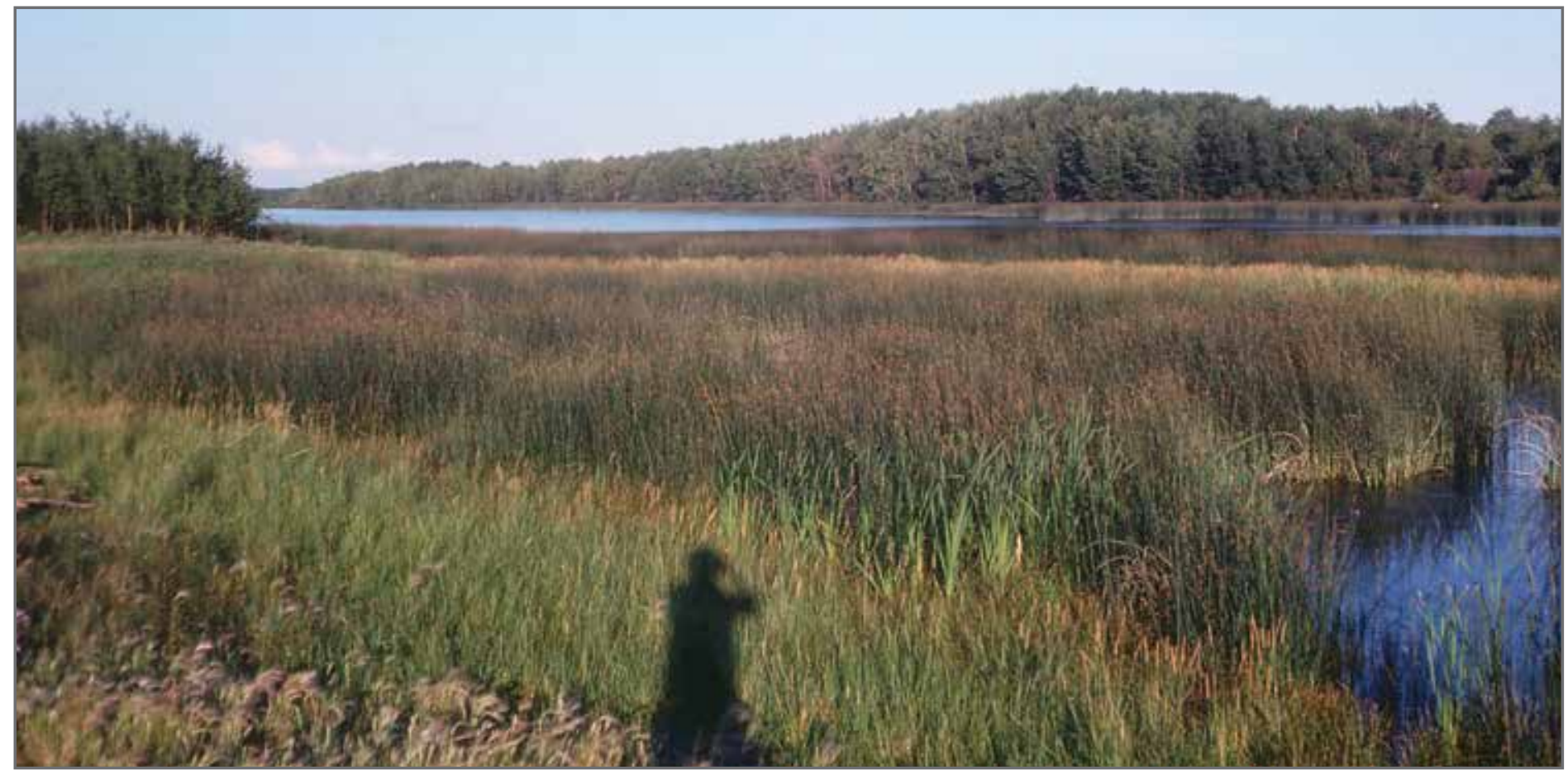

A view of Meadow Bank Lake and van Brienen property from the north shore. Photo credit: Sylvia (Harrison) van Brienen (deceased). 
go for the doctor in Wadena, some 16 miles away. William borrowed a horse to make the trip and, upon arrival, found that the doctor had been drinking. However, the lengthy January trip by horse and sleigh sobered the doctor up and he successfully delivered Eva (who would eventually become this writer's mother).

In the summer of 1908, in dire need of cash, Will went back to Manitoba to seek employment, leaving Henrietta alone on the homestead with the baby. There were neighbour women not far away but still Henrietta did not see her husband for five months. They were both good letter writers, however, and mail service was remarkably decent. Letters were exchanged on a near-weekly basis.

The Harrison cabin was within a stone's throw of a shallow water body with lots of boggy ground and tall grass nearby, which was a recipe for mosquitoes. It was decided that they could not remain on this spot for another summer and they began plans for a better building site, on higher ground, where bugs would be less prevalent.

The winter of 1908-09 was spent hauling wood for fuel and gathering logs for the new home. Good logs were not available close by and had to be hauled 15 to 20 miles. William's summer wages were enough to buy a team of oxen to do the job, but it took a lot of trips, three logs at a time. The second home was completed over a period of a few years. Four more children were born into the family and they lived in the log house for close to 60 years. Sylvia Harrison was the fourth child born on the homestead. She was born in 1919 .

The family survived, as most pioneering families did, by raising all kinds of livestock, growing a huge garden and picking wild fruit.
The parents were always busy with daily survival chores. In summer, the children largely entertained themselves by exploring the world around them. For the most part, that world was wilderness and everyone learned to appreciate nature.

The girls learned to milk cows and separate cream at an early age and the regular cream cheque was vital in securing cash to purchase necessities. Every afternoon, one or two of the girls would have to go out to the pasture to bring in the milk cows. Sometimes walking and sometimes on horseback, listening for the bell on the lead cow. It was the perfect time to observe the native flowering plants and try to put names to them. Mrs. Harrison was familiar with many of them, having grown up with an "English country garden". This would be the beginning of Sylvia's interest in botany, which would be a passion of hers for the rest of her life.

Sylvia was a meticulous student, attending a one-room country school and later completing high school in Wadena. After attending Business College, she had various jobs before landing a position as a secretary at Regina General Hospital. There she met Connie Pratt who introduced her to the Saskatchewan and the Regina Natural History Societies. They travelled around the province attending spring meets and other excursions. Sylvia also served on the SNHS board and on the committee that hosted the Canadian Nature Federation (CNF) conference in the 1960s. Mentors to Sylvia were the likes of George Ledingham, Stuart and Mary Houston, Margret Belcher, Jim Jowsey, Manley Callin, Lloyd T. Carmichael, Robert Nero, and the list goes on.

As she travelled around, Sylvia became aware of the need to preserve habitat as more and more land was being cultivated. Of

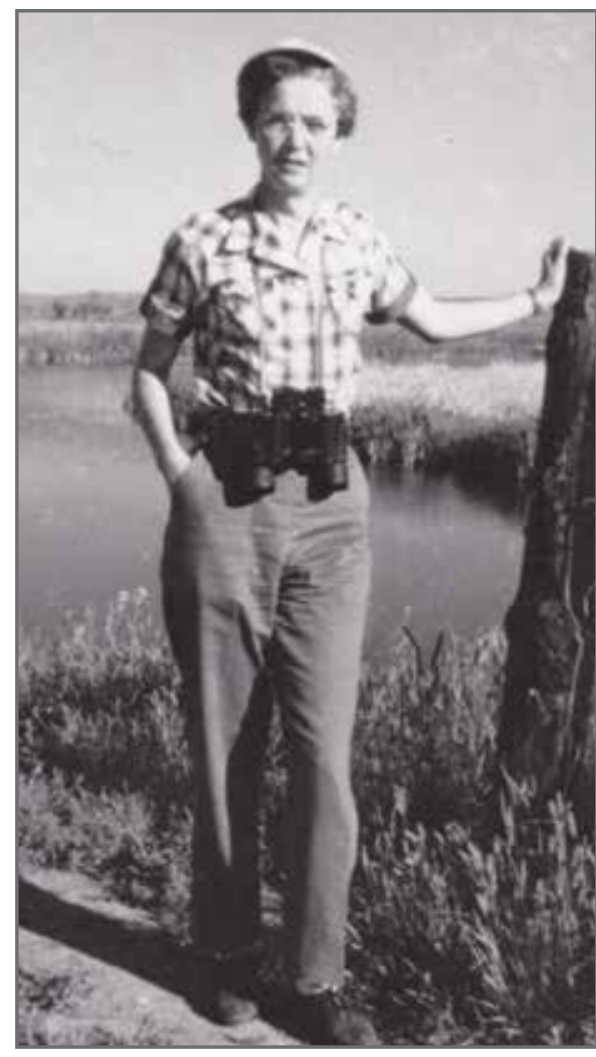

Sylvia Harrison in the early 1960 s Photo credit: Connie Pratt (deceased)

course, she noticed the same trend on her family farm as well. Prior to her father's death in 1963, she approached him asking if she could have the 40-acre parcel of land on the south side of Meadow Bank Lake with the intent of seeing it preserved for the long term. Her dad was happy to oblige.

In 1967, Sylvia married Anton van Brienen at the log home where she grew up. She had met Van (Anton) while attending a woodworking class he was teaching in Regina. He subsequently taught high school shop at Rosetown for many years and then they retired to Fosston, Saskatchewan. Although he was not an outdoorsman, Van fully supported Sylvia's passion for nature. During retirement they made frequent visits to her childhood home, always fascinated by the flora and fauna.

Sylvia van Brienen died in June of 1992 and the land title for her 40-acre property was transferred to Nature Saskatchewan on March 1, 1993. 